\title{
Zbrodnia katyńska jako ludobójstwo. Próba systematyzacji kwalifikacji prawnokarnej
}

\begin{abstract}
Abstrakt: W artykule wskazano na podstawy prawne kwalifikacji zbrodni katyńskiej w kategoriach ludobójstwa (genocide), polemicznie odnosząc się do argumentów wysuwanych przez Federację Rosyjską, która konsekwentnie neguje zasadność traktowania mordu dokonanego na mocy decyzji Politbiura KC WKP(b) z 5 III 1940 r. jako zbrodni nieulegającej przedawnieniu.
\end{abstract}

Słow a kluc zow e: zbrodnia katyńska, ludobójstwo, zbrodnia przeciwko ludzkości, zbrodnia wojenna, zwyczajowe prawo wojenne.

Abstract: The article indicates the legal basis for qualification of the Katyn Massacre in the category of genocide. Polemicising with the arguments put forward by the Russian Federation which persistently negates the validity of regarding the massacre perpetrated under the order of the Politbiuro of the Bolshevik Party Central Committee issued on 5 March 1940 as a non-expiring crime against humanity.

Keyw ords: Katyn massacre, genocide, crimes against humanity, crimes of war, customary laws of war.

4 III 2006 r. Generalna Prokuratura Wojskowa Federacji Rosyjskiej oświadczyła, że ofiary zbrodni katyńskiej nie były ofiarami represji stalinowskich. Jako uzasadnienie podano niemożność ustalenia kwalifikacji prawnej, na podstawie której skazano na śmierć jeńców wziętych do niewoli po agresji ZSRR na Polskę 17 IX 1939 r. Oświadczenie to było dopełnieniem - ogłoszonej wcześniej, 21 IX 2004 r. - odmowy uznania na podstawie zgromadzonego w śledztwie materiału zbrodni katyńskiej za ludobójstwo. Nie ujawniono także konkluzji śledztwa. W ten sposób Rosja odmówiła uznania masakry polskich jeńców za mord masowy wedle którejkolwiek ze stosowanych w prawie międzynarodowym 
i krajowym kwalifikacji prawnych: represji stalinowskiej, zbrodni wojennej, zbrodni przeciw ludzkości, ludobójstwa. Niemożność ustalenia, na podstawie jakich przepisów przeprowadzono egzekucje ofiar wymienionych w decyzji Politbiura Komitetu Centralnego Wszechzwiązkowej Komunistycznej Partii (bolszewików) [dalej: KC WKP(b)] z 5 III 1940 r., wskazuje na to, iż mieliśmy $\mathrm{w}$ tym wypadku do czynienia ze zbrodnią dokonaną z pominięciem procedur sądowniczych - jak w większości przypadków zbrodni ludobójstwa, których decyzje zapadały na szczeblu władz politycznych.

Na temat kwalifikacji prawnej zbrodni katyńskiej, w rozumieniu semantycznym jako zbrodni popełnionej na mocy decyzji KC WKP(b) z 5 III 1940 r., ukazało się wiele artykułów i publikacji zazwyczaj szczegółowo omawiających jeden aspekt ludobójstwa, jednak do tej pory nie ma całościowej, syntetycznej wykładni statusu prawnego tejże zbrodni. Co więcej, wciąż powstają kontrowersje na temat adekwatności określenia zbrodni katyńskiej jako genocide, co jest szczególnie bolesne dla rodzin ofiar. W niniejszym artykule chciałabym krótko zarysować podstawy prawne pozwalające na kwalifikację prawnokarna zbrodni katyńskiej jako zbrodni ludobójstwa.

Prawnokarną ocenę okoliczności związanych z podjęciem tzw. decyzji katyńskiej z 5 III 1940 r. i jej wykonaniem należy oceniać według stanu prawnego obowiąującego $\mathrm{w}$ czasie popełnienia zbrodni, mając na względzie zarówno obowiązujące wówczas przepisy prawa międzynarodowego, jak i wymóg bipenalizacji tzw. podwójnej bezprawności wobec przestępstw popełnionych poza granicami państwa ${ }^{1}$. Zbrodnia katyńska, pojmowana atomistycznie jako zabójstwo poszczególnych ofiar, była sprzeczna z art. 5 obowiązującego Kodeksu karnego z 1932 r. i art. 225 § 1 Rozporządzenia Prezydenta Rzeczypospolitej z 11 VII 1932 r., a także analogicznym art. I 37 Kodeksu karnego RFSRR obowiąującego od 1 I $1927 \mathrm{r}^{2}$

Pojęcie genocide (ludobójstwo) zostało wprowadzone do praktyki prawniczej pod koniec II wojny światowej, ale odwołuje się do typów przestępstw spenalizowanych ówcześnie w krajowych kodeksach karnych. Tak więc ludobójstwo - sprzeczne z normami uniwersalnymi - było w czasie II wojny światowej zbrodnią na gruncie międzynarodowego prawa zwyczajowego, zdefiniowana ex post przez Rafała Lemkina ${ }^{3}$. Konieczność prawnego sformułowania pojęcia

\footnotetext{
${ }^{1}$ Wymóg podwójnej bezprawności stanowi, że czyn popełniony przez sprawcę poza granicami państwa musi być spenalizowany zarówno w ustawie karnej krajowej, jak i w ustawie karnej obowiąującej w miejscu i czasie popełnienia wykroczenia.

${ }^{2}$ Spełnienie tego wymogu pozwala zgodnie z art. $110 \S 1 \mathrm{kk}$ i art. $111 \S 1 \mathrm{kk}$ na ściganie przez polskie organy wymiaru sprawiedliwości sprawców zbrodni katyńskiej. Śledztwo, prowadzone uprzednio bezowocnie przez Prokuraturę Generalną Wojskową Federacji Rosyjskiej, zgodnie z art. $114 \S 1 \mathrm{kk}$, nie stało na przeszkodzie wszczęcia śledztwa przez IPN o ten sam czyn zabroniony.

${ }^{3}$ Po raz pierwszy pojęcie genocide zostało użyte w $1944 \mathrm{r}$. przez polskiego prawnika pochodzenia żydowskiego Rafała Lemkina w rozdz. IX książki Axis Rule in Occupied Europe.
} 
wynikała z zaistniałych podczas wojny okoliczności, tj. rozmiarów i ciężaru gatunkowego zbrodni oraz braku możliwości sprawowania wymiaru sprawiedliwości w okresie dokonywania masowych egzekucji ${ }^{4}$. Stąd też stawianie

Rozumiał on termin „ludobójstwo” jako skoordynowane, planowe działanie, mające na celu zniszczenie istotnych podstaw życia grup narodowych, podejmowane z wyraźnym zamiarem unicestwienia tej grupy. Wywiódł termin z zaproponowanego przez siebie na dwóch Konferencjach dla Unifikacji Prawa Karnego: w Paryżu w 1931 r. i w Madrycie w 1933 r., pojęcia zbrodni barbarzyństwa, definiowanego jako karalne działanie przeciw życiu, nietykalności cielesnej, wolności, godności lub podstawie gospodarczej członków grup rasowych, religijnych lub społecznych, podejmowane z nienawiści lub z zamiarem zniszczenia tychże grup. Uważał, że w przypadku tego typu zbrodni sprawca czynem karalnym wymierzonym w poszczególne jednostki bezpośrednio lub pośrednio, skierowanym na zniszczenie kultury, języka, religii lub instytucji życia społeczno-politycznego, zmierza do wyrządzenia szkody grupie, do której należą dane jednostki. Działania sprawcy zbrodni niweluja poczucie bezpieczeństwa osobistego członków danej grupy, ich wolność oraz godność człowieka, a także zdrowie fizyczne i psychiczne. Zaproponowana przez Lemkina kategoria zbrodni barbarzyństwa obejmowała swym znaczeniem semantycznym zarówno zbrodnie przeciw ludzkości, jak i zbrodnię ludobójstwa w obecnym ich rozumieniu prawnokarnym, przy czym zaznaczał on, że zbrodnia barbarzyństwa może zaistnieć także w warunkach pokoju. Lemkin wskazywał, że ludobójstwo jest skoordynowanym procesem uderzajacym w podstawy bytu grup chronionych, niekoniecznie nastawionym na natychmiastowe ich zniszczenie, do czego jednak zmierza się w dłuższej perspektywie przez rozkład instytucji politycznych i społecznych, kultury, języka, poczucia wspólnotowego, religii, podstaw ekonomicznych grup chronionych a jednocześnie zniszczenie indywidualnego poczucia bezpieczeństwa, wolności, godności, zdrowia fizycznego bądź psychicznego, a nawet życia członków danej grupy. Ludobójstwo jest skierowane przeciw grupie chronionej jako całości, natomiast działania z nim związane zostają wymierzone w poszczególnych członków danej wspólnoty, choć nie mają charakteru indywidualnego. Zob. R. Lemkin, Axis Rule in Occupied Europe. Laws of Occupation, Analysis of Government, Proposals for Redress, Washington 1944, s. 79.

${ }^{4} \mathrm{Na}$ mocy art. 79 § 2 Konstytucji kwietniowej 30 III 1943 r. prezydent RP na uchodźstwie Władysław Raczkiewicz wydał dekret o odpowiedzialności karnej za zbrodnie wojenne. Artykuł I niniejszego dekretu stanowił, że odpowiedzialności karnej za przestępstwa dokonane po 31 VIII 1939 r. bez względu na miejsce ich popełnienia na mocy przepisów dekretu podlegają osoby przynależne do Rzeszy Niemieckiej bądź z nią sprzymierzone, współdziałające lub też działające w ich interesie. Zawarta w dekrecie klauzula o zawieszeniu biegu przedawnienia do upływu sześciu miesięcy od czasu wznowienia czynności przez polski Sąd Najwyższy odwoływała się do koncepcji spoczywania przedawnienia, sformowanej przez prof. Juliusza Makarewicza (zastosowanej w art. 88 kk z 1932 r.). Zob. A. Jankiewicz, Przygotowania Rzqdu RP w latach II wojny światowej do procesu zbrodniarzy hitlerowskich. Dekret prezydenta Rzeczypospolitej o odpowiedzialności karnej za zbrodnie wojenne, „Pamięć i Sprawiedliwość” 1997-1998, nr 40 s. 49-51, 53. Podpisana 30 X 1943 r. w Moskwie przez przedstawicieli ZSRR, USA, Wielkiej Brytanii i Republiki Chińskiej Deklaracja czterech mocarstw o okrucieństwach (Deklaracja w sprawie odpowiedzialności hitlerowców za popełnione przestępstwa (Deklaracja Moskiewska o Okrucieństwach), w: Prawo karne międzynarodowe. Wybór źródet, red. J. Izydorczyk, M. Królikowski, P. Wiliński, M. Znojek, Warszawa 2010, s. 49-50) mówiła o potrzebie stworzenia listy zbrodniarzy wojennych i odesłaniu ich do krajów, na których terytorium dopuścili się zbrodniczych aktów, w celu ich osądzenia i ukarania przez narody, które padły ofiarą ich przemocy. To zaś nie implikowało jurysdykcji narodów będących ofiarami zbrodniczych czynów, lecz 
zarzutu lex retro non agit wobec prawnej kwalifikacji zbrodni katyńskiej jako ludobójstwa świadczy jedynie o ignorancji publicystów piszących na ten temat ${ }^{5}$. Argumentum ad hominem, trzeba zaznaczyć, że w czasie procesu przed Międzynarodowym Trybunałem Wojskowym w Norymberdze strona radziecka traktowała zbrodnię katyńską jako ludobójstwo. 14 II 1946 r., podczas swojego wystapienia przed Trybunałem, sowiecki prokurator płk Jurij Pokrowski określił zbrodnię katyńską jako „fizyczną eksterminację narodów słowiańskich"6. Choć prokurator nie użył określenia genocide, to prezentował rzekomo hitlerowską zbrodnię jako egzemplifikację tej kategorii pojęciowej obejmującej najcięższą postać przestępstw popełnionych podczas II wojny światowej, do których osądzenia został powołany Międzynarodowy Trybunał Wojskowy ${ }^{7}$. Synonimiczne pojęcie „eksterminacja” odnosi do zbrodni przeciwko ludzkości popełnianych na ludności cywilnej ${ }^{8}$. Nie zostało ono natomiast użyte $\mathrm{w}$ stosunku do zbrodni wojennych ${ }^{9}$. W kontekście tego posługiwanie się przez radzieckich oskarżycieli określeniem „eksterminacja” dla oddania istoty zbrodni katyńskiej miało podkreślać jej ciężar gatunkowy w oskarżeniu

jurysdykcję państwa, na którego terytorium zbrodnie zostały dokonane. Zastanawiające jest to, czy władze ZSRR świadomie wprowadziły do Deklaracji zapis określający ratione loci jurysdykcji nad zbrodniarzami wojennymi. Wiedziały one już wówczas, że wszystkie miejsca masowych egzekucji i pochówku ofiar będą się znajdować jeśli nie na terytorium ZSRR, to przynajmniej w jego strefie wpływów. Deklaracja nie przewidywała jurysdykcji międzynarodowej. Sowieccy zbrodniarze zapewnili sobie bezpieczeństwo. Norma ta została przyjęta $\mathrm{w}$ zasadach jurysdykcji norymberskiej na podstawie porozumienia londyńskiego, obejmując bezpośrednio jedynie zbrodniarzy wojennych, których czyny przestępcze nie dały się powiązać z żadnym określonym miejscem.

${ }^{5} \mathrm{Na}$ marginesie warto zauważyć, że radziecki Kodeks postępowania karnego z $1926 \mathrm{r}$. nie zawierał fundamentalnej i uznanej we wszystkich innych systemach prawnych krajów europejskich zasady lex retro non agit i zasady nullum crimen sine lege. Art. I 6 kodeksu powtarzał za Kodeksem karnym z 1922 r. zasadę analogia legis (,Jeśli jakiekolwiek społecznie niebezpieczne działanie nie jest wprost przewidziane w kodeksie niniejszym, wówczas zasadę i zakres odpowiedzialności za nie określa się zgodnie z tymi artykułami kodeksu, które przewidują następstwa najbardziej podobne co do rodzaju"). W praktyce represyjnego systemu stalinowskiego zapis ten dawał możliwość wykazania czynu społecznie niebezpiecznego bez odwołania do naruszenia jakiegokolwiek przepisu Kodeksu karnego według zasady „dajcie człowieka, a znajdzie się artykuł” i prewencyjnego ukarania pod pozorem zapobiegania przestępstwu przez zastosowanie środków ochrony społecznej. Tak więc obrońcy stanowiska rosyjskiego, kontestujący temporalną właściwość określenia zbrodni katyńskiej jako ludobójstwa zgodnie z definicją wyrażoną w Rezolucji ONZ z 1948 r., nie powinni powoływać się na ten argument, skoro prawo karne sprawcy zbrodni i państwa właściwego do przeprowadzenia procesu śledczo-karnego w sprawie zbrodni dokonanej na jego terytorium w inkryminowanym czasie nie kierowało się powyższą zasadą prawa rzymskiego.

${ }^{6}$ Trial of the Major War Criminals before International Military Tribunal. Official Text, t. VII, Nuremberg 1974, s. 428.

${ }^{7}$ Karta Międzynarodowego Trybunału Wojskowego, Dz.U. 1945, nr 63, poz. 367.

8 Art. 6 pkt c Statutu MTW.

${ }_{9}$ Art. 6 pkt b Statutu MTW. 
Sztabu 537 Batalionu Łączności o okrucieństwo wobec bezbronnych jeńców, przekraczające znamiona jedynie zbrodni wojennej. Pojęcie „ludobójstwo” pojawiało się $\mathrm{w}$ procesie norymberskim $\mathrm{w}$ odniesieniu do poszczególnych zbrodni przeciwko ludzkości, takich jak zbrodnia katyńska, nie wprost jako kwalifikacja prawna, ale jako jedno z określeń opisowych ${ }^{10}$. Trzeba podkreślić, że zbrodnia przeciwko ludzkości nie była tożsama z pojęciem ludobójstwa ${ }^{11}$. To rozróżnienie jasno zostało wyłożone w Statucie Rzymskim.

Retroaktywne zasady prawa międzynarodowego przyjęte w Statucie Trybunału Norymberskiego i rozwinięte w wyroku Międzynarodowego Trybunału Wojskowego zostały potwierdzone przez Rezolucję Zgromadzenia Ogólnego ONZ z 11 XII 1946 r. i uściślone w Konwencji Zgromadzenia Ogólnego ONZ w sprawie zapobiegania i karania zbrodni ludobójstwa z 9 XII 1948 r. Po wojnie, w 1947 r. amerykański Trybunał Wojskowy w procesie Josepha Altstöttera (tzw. proces prawników) stwierdził, że Zgromadzenie Ogólne Organizacji Narodów Zjednoczonych nie jest organem prawodawczym, ale posiada najwyższy autorytet do wyrażania opinii świata, także penalizacji ex post zbrodni ludobójstwa. Trybunał uznał, że karanie sprawców ludobójstwa można uzasadnić, gdyż w chwili dokonywania zbrodni musieli mieć oni świadomość, że ich czyny są złe moralnie, a zarazem bezprawne. Ponadto stanowisko prawne musi być względnie proste i niedogmatyczne, opierać się na powszechnym poczuciu sprawiedliwości, by legalizm nie udaremnił możliwości osądzenia i ukarania winnych najcięższych zbrodni.

Kwestia zdefiniowania terminu genocide została podjęta podczas pierwszej sesji Zgromadzenia Ogólnego ONZ 11 XII 1946 r. Podczas rozważań przyjętej jednomyślnie rezolucji nr 96 zbrodnię ludobójstwa określano początkowo jako „odmówienie prawa do życia grupie ludzkiej, w wyniku czego grupy rasowe, religijne, polityczne czy inne są zniszczone częściowo lub w całości”. Użycie słów „polityczne czy inne” wzbudziło jednak sprzeciw ZSRR ze względu na możliwość odniesienia ich do zbrodni komunistycznych, w szczególności

${ }^{10}$ Expressis verbis zarzut umyślnego i systematycznego ludobójstwa, rozumianego jako eksterminacja, narodowych i religijnych, a nawet rasowych (co stanowi poszerzenie definicji ludobójstwa według Rafała Lemkina) grup zamieszkujacych tereny okupowane, został przedstawiony 24 oskarżonym w akcie z 6 X 1945 r.

$11 \mathrm{~W}$ okresie powojennym $\mathrm{w}$ środowisku prawniczym zaznaczyła się różnica stanowisk co do relacji między zbrodnia przeciwko ludzkości a zbrodnią ludobójstwa. Część prawników uważała, że ludobójstwo jest kwalifikowaną zbrodnią przeciwko ludzkości. Inni zaś twierdzili, że to odrębna kategoria zbrodni. Biorac pod uwagę obecny stan prawa międzynarodowego oraz uwzględniając definicje ujęte w statutach powstałych ad hoc międzynarodowych trybunałów karnych i Statucie Międzynarodowego Trybunału Karnego, należy przyznać im rację. Oba typy zbrodni odróżnia cel, jaki w przypadku zbrodni ludobójstwa stanowi unicestwienie grupy chronionej. Waga crime of all crimes jest cięższa ze względu na selekcję ofiar pod względem przynależności do stałej grupy, w której członkostwo jest nadprzyrodzone. Zbrodnię przeciwko ludzkości i ludobójstwo należy kwalifikować jako przestępstwo przeciwko ludzkości - delicta iuris gentium. 
podejmowanych wówczas na forum międzynarodowym kwestii przestępstw $\mathrm{w}$ stosunku do anektowanych państw bałtyckich. Wobec niechęci aliantów do zadrażniania stosunków z Sowietami sprzeciw ten został uwzględniony. Zgromadzenie przegłosowało w następnym dniu rezolucję zawierająca przedmiotowo węższą od pierwotnej definicję zbrodni ludobójstwa, z widoczną intencją ograniczenia jej do rasowo-etnicznych zbrodni hitlerowskich, wykluczenia zaś klasowych zbrodni stalinowskich. To odcisnęło silne piętno na wszystkich jurystycznych definicjach zbrodni ludobójstwa, a także historycznym i socjologicznym podejściu do tego zjawiska.

9 XII 1948 r. Zgromadzenie Ogólne ONZ jednomyślnie przyjęło Rezolucję 260 A (III) w sprawie zapobiegania i karania zbrodni ludobójstwa ${ }^{12}$. W art. II sformułowano przedmiotowo-podmiotową definicję zbrodni. Ludobójstwo zostało określone jako jeden z następujących czynów, popełniony w zamiarze zniszczenia w całości lub części homogenicznych, stabilnych grup narodowych, etnicznych, rasowych lub religijnych jako takich:

- zabójstwo członków grupy;

- spowodowanie poważnego uszkodzenia ciała lub rozstroju zdrowia psychicznego członków grupy, przy czym uszczerbek na zdrowiu nie musi być ani trwały, ani nieodwracalny;

- rozmyślne stworzenie dla członków grupy warunków życia obliczonych na spowodowanie ich całkowitego lub częściowego zniszczenia fizycznego, występujących w okresie, który rzeczywiście może pozwolić na efektywna realizację zamierzonego planu destrukcji;

- stosowanie środków mających na celu wstrzymanie prokreacji w obrębie grupy;

- przymusowe przekazywanie dzieci członków grupy do innej grupy.

W powyższej definicji ludobójstwa można wyróżnić dwa elementy: wskazanie ogólnych znamion zbrodni oraz enumeratywne wymienienie czynów sprawcy. Zaistnienie obydwu tych elementów jest warunkiem sine qua non odpowiedzialności karnej z tytułu ludobójstwa. Odpowiedzialność karna wymaga zaistnienia dolus specialis - szczególnego zamiaru zniszczenia wyłącznie grupy chronionej wymienionej w Rezolucji, tzn., że zabicie członka grupy chronionej, któremu nie towarzyszy zamiar zniszczenia danej grupy jako takiej w całości lub części, nie jest ludobójstwem. Czyn

${ }^{12}$ Konwencja w sprawie zapobiegania i karania zbrodni ludobójstwa, Dz.U. 1952, nr 2, poz. 9. W czasie prac nad Konwencją lobby ZSRR prowadziło agitację nad zawężeniem prawnej definicji ludobójstwa do zbrodni faszystowskich oraz zbrodni rasowych. W ten sposób zapewne Związek Sowiecki chciał zapewnić sobie gwarancję braku odpowiedzialności za zbrodnie dokonane po wybuchu rewolucji październikowej. Kraje sowieckie co prawda ratyfikowały Konwencję z 9 XII 1948 r., ale z wyłączeniem art. IX, dotyczącego oddania spornych kwestii pod jurysdykcję Międzynarodowego Trybunału Sprawiedliwości na żądanie jednej ze stron. Sowieci, będąc ofiarami zbrodni nazistowskich a jednocześnie sprawcami podobnych zbrodni na terenach zajętych, obawiali się takiej jurysdykcji. 
karalny w myśl art. III Rezolucji stanowią także zmowa w celu popełnienia ludobójstwa, publiczne, bezpośrednie podżeganie do niego, jego usiłowanie oraz współudział.

Kontrowersje budzi stosowanie art. 2 Konwencji z 9 XII 1948 r. w ocenie celowości działania sprawców zbrodni, tzn. czy zbrodnia katyńska została popełniona $\mathrm{w}$ zamiarze zniszczenia całości lub też części narodu, czy też jedynie grup politycznych. Art. I $18 \S 1$ polskiego Kodeksu karnego ${ }^{13}$ pojęcie „ludobójstwo” odnosi nie tylko do eksterminacji grup narodowych, etnicznych, rasowych lub religijnych, ale rozszerza zakres podmiotowo-przedmiotowy definicji na grupy polityczne i grupy o określonym światopoglądzie.

Już pobieżna lektura notatki ludowego komisarza spraw wewnętrznych ZSRR Ławrientija Berii ${ }^{14}$ zwraca uwagę na nagromadzenie epitetów kategoryzujących winnych kontrrewolucyjnych wykroczeń jako członków grupy narodowościowej. Szef NKWD wnioskował o rozpatrzenie sprawy w trybie specjalnym, z zastosowaniem najwyższego wymiaru kary wobec „byłych oficerów armii polskiej, byłych pracowników polskiej policji i organów wywiadu, członków polskich nacjonalistycznych kontrrewolucyjnych organizacji powstańczych, uciekinierów". W swej notatce zaznaczył, że w trzech obozach jenieckich Polacy stanowili 97\%, a w więzieniach wewnętrznych NKWD - ok. 57,3\%, tymczasem szacuje się, że Polacy stanowili 1/3 ogólnej liczby więźniów ${ }^{15}$. W orzeczeniu Komisji Ekspertów z 2 VIII 1993 r. stwierdzono, że przynależność do narodowości polskiej traktowano samą w sobie jako okoliczność obciążająca ${ }^{16}$. Należy także zwrócić uwagę, że liczba zadysponowanych była dużo niższa niż rozstrzelanych. Przypuszcza się, że w chwili wydania decyzji znajdowali się oni już w czterech docelowych więzieniach: w Charkowie, Chersoniu, Kijowie i Mińsku. Sławomir Kalbarczyk analizujacc informacje biograficzne o rozstrzelanych, zauważył, że wielu spośród zamordowanych zostało aresztowanych już po zapadnięciu tzw. decyzji katyńskiej, w kwietniu, a nawet maju $1940 \mathrm{r.}{ }^{17}$, stąd w notatce nie mogły być przewidziane rzeczywiste dane statystyczne odnoszące się do narodowości więźniów z tzw. Zachodniej Białorusi i Zachodniej Ukrainy.

${ }^{13}$ Art. $118 \S 1$ rozdz. XVI kk: Przestępstwa przeciwko pokojowi, ludzkości oraz przestępstwa wojenne określenie ludobójstwo. Dz.U. 1997, nr 98, poz. 553 z późn. zm.

${ }^{14} 1940$ marzec 5, Moskwa - Notatka Ł. Berii do J. Stalina z propozycją wymordowania polskich jeńców wojennych, w: Katyń. Dokumenty zbrodni. t. I: Jeńcy niewypowiedzianej wojny sierpień 1939 - marzec 1940, red. A. Gieysztor, R.G. Pichoja i in., Warszawa 1995, s. $469-475$.

151940 marzec 5, Moskwa - Notatka Ł. Berii do J. Stalina z propozycją wymordowania polskich jeńców wojennych, w: Katyń. Dokumenty zbrodni..., t. I, s. 470.

${ }_{16}$ Orzeczenie komisji ekspertów (2 sierpnia 1993), w: Rosja a Katyń, red. A. Dzienkiewicz, Warszawa 2010, s. 71.

${ }^{17}$ Badacze tematyki wciąż nie wiedzą nic o nie mniej niż 1305 ofiarach zbrodni katyńskiej. Zob. S. Kalbarczyk, Zbrodnia katyńska po 70 latach. Krótki przeglad ustaleń historiografii, w: Zbrodnia katyńska. W kregu prawdy i ktamstwa, red. S. Kalbarczyk, Warszawa 2010, s. 12. 
Mord dokonany na co najmniej 21819 osobach, świadomie ze względu na przynależność narodową ofiar, miał na celu przeciwdziałanie ruchowi narodowowyzwoleńczemu na rzecz odrodzenia państwowości polskiej. W swej notatce Beria wyliczał kategorie osób wchodzacych w skład grupy podmiotowej decyzji katyńskiej według przynależności klasowej, społeczno-zawodowej, bez wskazania zarzucanych czynów karalnych ani kwalifikacji prawnokarnej podejmowanych przez nich działań.

Strona rosyjska i polska sa zgodne, że zamordowani na mocy decyzji katyńskiej to jeńcy wojenni lub byli polscy oficerowie - przebywający $\mathrm{w}$ więzieniach wewnętrznych NKWD na terenie tzw. Zachodniej Białorusi i Zachodniej Ukrainie. W argumentacji rosyjskiej, według której zamordowani jeńcy nie stanowili jednolitej grupy narodowościowej, widać niekonsekwencję. Przyjmując aplikację zwyczajów wojennych, należy zadać pytanie, czy w ogóle Białorusini, Ukraińcy, Żydzi wzięci do niewoli po 17 IX 1939 r. mogli otrzymać status jeńców wojennych, skoro przecież Związek Radziecki wojnę toczył rzekomo o oswobodzenie ziem Zachodniej Ukrainy i Zachodniej Białorusi „z jarzma polskiego ucisku”, a następnie przyłączył je na mocy poparcia udzielonego w wolnym plebiscycie. To, że ci Białorusini, Ukraińcy, Żydzi znaleźli się w obozach jenieckich i nie zostali zwolnieni z nich w październiku wraz z współziomkami, świadczy o tym, że władza sowiecka uznała ich za element polski ${ }^{18}$, stanowiący zagrożenie dla integralności ZSRR, lub propolski, czyli również antysowiecki.

Do czasu zakończenia pertraktacji z III Rzesza 42492 jeńców zostało zatrzymanych w obozach w Kozielsku i Putywlu. W listopadzie 1939 r. szef Zarządu do Spraw Jeńców Wojennych mjr Piotr Soprunienko wnioskował do komisarza ludowego spraw wewnętrznych Berii ${ }^{19}$ o zwolnienie do domów mieszkańców tzw. Zachodniej Ukrainy i Zachodniej Białorusi, motywując tym, że ich dalsze przetrzymywanie w obozach było sprzeczne z uchwałą piątej nadzwyczajnej sesji Rady Najwyższej ZSRR z 2 XI 1939 r. Propozycja ta nie została jednak uwzględniona przez Berię.

Początkowo, jeszcze w połowie października 1939 r. Zarząd do Spraw Jeńców Wojennych polecił wykonać władzom poszczególnych obozów statystykę narodowościową jeńców, którzy mieli zostać przekazani Niemcom ${ }^{20}$. W późniejszych dokumentach sowieckich niezwykle rzadko rozróżniano oficerów

${ }^{18}$ Stanisław Starzewski i Kazimierz Zamorski cytują relację K.Z.: „Toteż powiedzenie Ukraińców: «Polacy uczyli nas być Polakami przez 20 lat i nie nauczyli, a bolszewicy zrobili nas Polakami w ciagu dwóch miesięcy» ma na tle niespotykanej w żadnym kraju, bezwzględnej tyranii i zakłamania swoje pełne uzasadnienie". K. Zamorski, S. Starzewski, Sprawiedliwość sowiecka, Warszawa 1994, s. 186.

191939 listopad, Moskwa - Pismo Zarządu JW. Do Ł. Berii z propozycją zwolnienia z obozów części jeńców wojennych, w: Katyń. Dokumenty zbrodni..., t. I, s. 285-286.

${ }^{20} 1939$ październik [nie później 23], [b.m.w.] - Informacja P. Soprunienki o składzie narodowościowym jeńców wojennych szeregowców i podoficerów podlegających wymianie z Niemcami, przetrzymywanych w sześciu obozach, w: Katyń. Dokumenty zbrodni..., t. I, s. 211. 
- polskich jeńców wojennych według ich narodowości, z tym, że łącznie wymieniani sa mieszkańcy Zachodniej Białorusi i Zachodniej Ukrainy - jako obywateli ZSRR wraz z Polakami (mieszkańcami terenów zagarniętych przez ZSRR ${ }^{21}$ ), czasami mieszkańców terytoriów przyłączonych do Litwy i mieszkańców terenów włączonych do Niemiec ze względu na potencjalną możliwość ich przekazania władzom III Rzeszy ${ }^{22}$. Sformułowanie „mieszkańcy Zachodniej Białorusi i Zachodniej Ukrainy" nie jest tożsame z określeniem narodowości „Białorusini i Ukraińcy”. Często natomiast oficerzy z obozów jenieckich i więzień wewnętrznych byli różnicowani pod względem stopnia wojskowego.

Przed podjęciem decyzji katyńskiej mjr Soprunienko przekazał do Moskwy dane statystyczne odnoszące się zarówno do struktury narodowościowej jeńców poszczególnych obozów ${ }^{23}$, jak i ich stopni wojskowych, policyjnych i sprawowanych urzędów cywilnych ${ }^{24}$. Sporządzono również statystykę struktury narodowościowej jeńców obozu kozielskiego i starobielskiego mieszkających na terenach Zachodniej Białorusi i Zachodniej Ukrainy ${ }^{25}$. W połowie marca, gdy przygotowywano się do przeprowadzenia egzekucji na podstawie decyzji katyńskiej, Zarząd do Spraw Jeńców Wojennych dokonał zestawienia składu narodowościowego i terytorialnego - według województw II Rzeczypospolitej - jeńców wojennych z wyróżnieniem sprawowanych funkcji w policji i żandarmerii ${ }^{26}$ oraz wojsku ${ }^{27}$, a także zestawienia statystycznego $\mathrm{z}$ rozbiciem na stopnie wojskowe i piastowane urzędy w administracji cywilnej. Wobec

211940 luty [10], Moskwa - Informacja Zarządu JW o stanie liczebnym jeńców przetrzymywanych w obozach w Ostaszkowie, Starobielsku i Kozielsku - z podziałem według stopni i pochodzenia terytorialnego, w: Katyń. Dokumenty zbrodni..., t. I, s. 414-420.

${ }^{22}$ Zob. m.in.: 1939 grudzień 29, Moskwa - Informacja P. Soprunienki o stanie liczebnym oficerów, policjantów i żandarmów przebywających w obozach jenieckich, w: Katyń. Dokumenty zbrodni..., t. I, s. 334.

${ }^{23} 1940$ luty [28], Moskwa - Informacja P. Soprunienki o składzie narodowościowym jeńców wojennych - oficerów z obozów w Starobielsku i Kozielsku, w: Katyń. Dokumenty zbrodni..., t. I, s. 451-452; 1940 luty [28], Moskwa - Informacja P. Soprunienki o składzie narodowościowym jeńców wojennych z obozów pracy, w: Katyń. Dokumenty zbrodni..., t. I, s. 453-454.

${ }^{24} 1940$ marzec 2, Moskwa - Informacja P. Soprunienki o liczbie jeńców wojennych i żandarmów, w: Katyń. Dokumenty zbrodni..., t. I, s. 457-458; 1940 marzec 2, Moskwa - Informacja P. Soprunienki o liczbie oficerów znajdujących się w obozach jenieckich, w: Katyń. Dokumenty zbrodni..., t. I, s. 458-459; 1940 marzec 3, Moskwa - Informacja P. Soprunienki o liczbie jeńców - cywilów znajdujących się w obozach, w: Katyń. Dokumenty zbrodni..., t. I, s. 461-462.

251940 marzec [3], Moskwa - Informacja P. Soprunienki o liczbie jeńców wojennych pochodzących z terenów Zachodniej Białorusi i Ukrainy, w: Katyń. Dokumenty zbrodni..., t. I, s. $466-467$.

${ }^{26} 1940$ marzec [16], Moskwa - Informacja Zarządu JW o stanie liczebnym jeńców wojennych policjantów i żandarmów przetrzymywanych w obozie ostaszkowskim, w: Katyń. Dokumenty zbrodni, t. II: Zagtada marzec - czerwiec 1940, red. A. Gieysztor, W. Kozłow i in., Warszawa 1998, s. 65-67.

271940 marzec [16], Moskwa - Informacja Zarządu JW o stanie liczebnym jeńców wojennych przetrzymywanych w trzech obozach specjalnych, w: Katyń. Dokumenty zbrodni..., t. II, s. $67-74$. 
sprzeczności w danych statystycznych przesyłanych przez władze obozów jenieckich do Zarządu do Spraw Jeńców Wojennych ${ }^{28}$ oszacowanie ofiar zbrodni katyńskiej poszczególnych narodowości należy uznać za bezcelowe ${ }^{29}$. Strona polska nie dysponuje żadnymi innymi dokumentami podającymi liczbę jeńców poszczególnych narodowości. Informacje te nie były zamieszczane na listach transportowych stanowiaccych podstawę opracowania tzw. list katyńskich, zawierajacych nazwiska ofiar zbrodni. Badania prozopograficzne w odniesieniu do poszczególnych narodowości osób zamordowanych nie zostały przeprowadzone. Błędem byłoby wnioskowanie o narodowości na podstawie miejsca urodzenia ofiar ${ }^{30}$. Wiemy, że wśród zamordowanych byli także nieujęci w statystyce władz obozowych Gruzini - oficerowie kontraktowi w WP ${ }^{31}$ czy Węgrzy.

${ }^{28}$ Zob. też: 1939 listopad 2, Ostaszków - Meldunek naczelnika oddziału specjalnego G. Korytowa do NKWD w sprawie stanu ewidencji jeńców wojennych w obozie, w: Katyń. Dokumenty zbrodni..., t. I, s. 233; 1939 listopad [nie wcześniej niż 15], Moskwa - Raport kierownictwa Zarządu JW o stanie podległych mu obozów jenieckich, w: Katyń. Dokumenty zbrodni..., t. I, s. 260; 1939 listopad 21, Ostaszków - Raport inspektora Zarządu JW A. Makarowa do I. Maklarskiego o przebiegu pracy ewidencjonowania jeńców wojennych, w: Katyń. Dokumenty zbrodni..., t. I, s. 275-276; 1939 grudzień [nie wcześniej niż 1], Kozielsk - Raport D. Kabanowa dla I. Maklarskiego o stanie ewidencji w obozie kozielskim, w: Katyń. Dokumenty zbrodni..., t. I, s. 289-290; 1939 grudzień [nie później niż 4], Ostaszków - Raport inspektorów Zarządu JW dla I. Maklarskiego o przebiegu prac ewidencyjnych w obozie, w: Katyń. Dokumenty zbrodni..., t. I, s. 307-309; 1939 grudzień 9, [b.m.w] - Raport A. Tiszkowa dla kierownika Zarządu JW o stanie obozu ostaszkowskiego, w: Katyń. Dokumenty zbrodni..., t. I, s. 316-317.

„Ewidencja jeńców wojennych znajduje się w chaotycznym stanie.

Nikt nie potrafi dokładnie powiedzieć, ilu jest jeńców wojennych w obozie. [...]

Stan aktualny nie zgadza się z liczbą akt ewidencyjnych. Pewna liczba jeńców wojennych uchyliła się od rejestracji, jednakże nie wiadomo, kto się uchylił, ponieważ nie było jeszcze zestawienia stanu faktycznego $\mathrm{z}$ aktami ewidencyjnymi. [...]

Kwestionariusze osobowe wypełniali ludzie o niskich kwalifikacjach (rejestratorzy, czerwonoarmiści). Oddział specjalny nie zważając na dyrektywę Narkoma uchylił się od tej sprawy, a wyznaczony do rejestrowania jeńców wojennych instruktor oddziału polit[ycznego] IWANOW odniósł się do sporządzania kwestionariuszy osobowych z wyjątkowym niedbalstwem, wypełniał kwestionariusze na tyle niewyraźnie i niewłaściwie, że znacząco utrudnił i zatrzymał pracę innych pracowników. [...] Do tej pracy powinno się brać osoby, które skończyły przynajmniej dziesięć klas, a faktycznie rejestratorzy spośród przypisańców okazali się po prostu półanalfabetami, nie będącymi w stanie prawidłowo wypełnić kwestionariuszy osobowych". Ibidem, s. 316-317. Por. 1940 styczeń 31, Starobielsk - Wytyczne pokontrolne Zarządu JW dla komendy obozu starobielskiego, w: Katyń. Dokumenty zbrodni..., t. I, s. 386.

${ }^{29}$ Zob. J. Kurczab, Struktura narodowościowa i wyznaniowa Ofiar Zbrodni Katyńskiej, opracowanie wewnętrzne Centralnej Biblioteki Wojskowej im. Marszałka Józefa Piłsudskiego w Warszawie, Warszawa 2015.

${ }^{30}$ Chociażby w przypadku kpt. Franciszka Pietrzaka urodzonego w Lütgen w Niemczech, uczestnika powstania wielkopolskiego, zamordowanego w Katyniu. Katyń. Księa Cmentarna Polskiego Cmentarza Wojennego, Warszawa 2000, s. 480.

${ }^{31}$ W. Materski, Gruzini - ofiary zbrodni katyńskiej. Dokument z postsowieckiego zasobu archiwalnego, „Pro Georgia” 2004, nr 11, s. 89-93. 
Mówiąc o ofiarach zbrodni katyńskiej trzeba mieć na uwadze ich wielokrotna definicję podmiotowa, niezwykle istotną dla ustalenia kwalifikacji prawnokarnej zbrodni. W kwalifikacji prawnokarnej czynów zabronionych niedopuszczalna jest alternatywa rozłączna. Osoby tworzace docelową grupę decyzji katyńskiej Politbiura KC WKP(b) z 5 marca stanowili grupę etniczna obywateli II Rzeczypospolitej, a przy tym tworzyli grupę uznaną przez najwyższe władze Związku Sowieckiego za wrogą i niebezpieczną dla ustroju komunistycznego ze względu na narodowość polska.

$\mathrm{Na}$ mocy decyzji KC WKP(b) z 5 III 1940 r. dokonano zagłady obywateli II Rzeczypospolitej. Trzeba pamiętać, że państwo polskie odrodzone po I wojnie światowej było wielonarodowościowe, stąd liczne mniejszości narodowościowe funkcjonowały w ramach struktury etnicznej narodu II RP jako jej komplementarne pierwiastki. Taką wykładnię narodu polskiego przyjęto $\mathrm{w}$ doktrynie prawa karnego w komentarzu do art. 159 Kodeksu karnego z 1932 r., obejmując pojęciem prawnym „naród polski” ogół obywateli państwa polskiego bez względu na ich narodowościowośśc ${ }^{32}$. Takie samo prawne rozumienie pojęcia „naród” występowało w prawodawstwie sowieckim ${ }^{33}$. Po przymusowej akcji paszportyzacji władze radzieckie traktowały osoby pochodzące z tzw. Zachodniej Białorusi i Zachodniej Ukrainy jako obywateli ZSRR, stanowiącego również konglomerat narodowościowy.

Polscy obywatele narodowości ukraińskiej, białoruskiej żydowskiej czy jakiejkolwiek innej nie zostali w dokumentach sowieckich wymienieni oddzielnie, a decyzja najwyższych władz ZSRR docelowo dotyczyła grupy obywateli byłego państwa polskiego, tworzacych naród II Rzeczypospolitej. Nawet, jeśli przyjmiemy obecne rozumienie narodu - co jest błędem z punktu racjonalności ogólnej - zamordowani, określeni w decyzji katyńskiej jako zatwardziali wrogowie władzy radzieckiej, przepełnieni nienawiścią do radzieckiego ustroju, stanowili część chronionej wielonarodowościowej grupy etnicznej II RP, która charakteryzowały wspólny język i kultura. Zginęli w etnicznym rozumieniu jako Polacy, niejako skażeni polskością. Trzeba pamiętać, że o kwalifikacji grupy decyduje subiektywne postrzeganie jej przez sprawcę czynu zabronionego. Żaden dokument, dekretujący wykonanie zbrodni, nie wymienia osobno

32 Art. 159 kk z 1932 r.: „Kto publicznie lży lub wyszydza Naród lub Państwo Polskie...”

${ }^{33}$ Deklaracja praw ludu pracującego i wyzyskiwanego, w: Źródta do historii powszechnej okresu międzywojennego, t. I: 1917-1926, red. S. Sierpowski, Poznań 1989, s. 33; F. Ancewicz, Stalinowska koncepcja państwa na tle ewolucji ustrojowej Zwiazku Socjalistycznych Republik Radzieckich, Lublin 2001, s. 47-48, 117-120, 147, 149, 174, 190, 196; S. Ehrlich, Państwo Radzieckie, seria: „Biblioteka Wiedzy o Związku Radzieckim”, nr 1, Warszawa 1950, s. 42-43; K. Grzybowski, Ustrój Zwiazku Socjalistycznych Sowieckich Republik, „Przegląd Współczesny” R. VII, 1928, t. XXVII, nr 79, s. 308-309; W. Wielhorski, Los Polaków w niewoli sowieckiej (1939-1956), Londyn 1956, s. 5-6; M. Iwanow, Pierwszy naród ukarany. Stalinizm wobec polskiej ludności kresowej (1921-1938), Warszawa 1991, s. $17-18,22-23,126$. 
innych narodowości poza polską. Także i osoby biorące udział w egzekucjach, jak również pracownicy więzień wewnętrznych NKWD postrzegali przybywających do więzien jako Polaków, o czym świadczą określenia zamordowanych, jakimi posługiwali się świadkowie, zeznając w śledztwie prowadzonym w latach 1990-1994 przez Główną Prokuraturę Wojskową Federacji Rosyjskiej.

Prokurator Małgorzata Kuźniar-Plota, uzasadniając kwalifikację prawnokarna zbrodni katyńskiej, utożsamia objętą decyzją Politbiura KC WKP(b) z 5 III 1940 r. część grupy narodowej II Rzeczypospolitej z grupą obywatelska. Zatarcie w tym wypadku dystynkcji między przynależnością narodowościa a obywatelstwem, wobec toczacych się $\mathrm{w}$ dwudziestoleciu międzywojennym dyskusji nad zdefiniowaniem przynależności narodowościowej, nie jest oczywiste ${ }^{34}$.

34 Juliusz Makarewicz w komentarzu do Kodeksu karnego w oparciu o wykładnię art. 152 kk uzasadniał, że nie należy utożsamiać grupy narodowej polskiej z grupą narodowościową etniczna, gdyż pojęcie narodu jest w polskiej tradycji synonimem społeczeństwa, ogółu obywateli w przeciwstawieniu do państwa. (Zob. J. Makarewicz, Wykładnia kodeksu karnego. Naród Polski, „Gazeta Sądowa Warszawska” R. LXI, 1934, nr 26, s. 386-388). Odmienny pogląd prezentował prokurator Karol Kowalski, który postrzegał taką interpretację wykładni kodeksu jako środek przymusu asymilacji narodowej. Zdefiniowanie grupy narodowej w kategoriach etnicznych w art. $152 \mathrm{kk}$ implikowałoby nierówne traktowanie obywateli II RP przynależnych do mniejszości narodowościowych, co byłoby oczywiście sprzeczne z traktatem o mniejszościach narodowych i konstytucją marcową. (Zob. K. Kowalski, Polski kodeks karny $w$ dotychczasowej praktyce, „Czasopismo Sędziowskie” R. VIII, 1934, nr 3, s. 183). Marceli Handelsman w referacie wygłoszonym podczas posiedzenia Instytutu do Badań Spraw Narodowościowych w listopadzie 1922 r. definiował naród jako zbiorowa świadomość łączności grup zamieszkujących zazwyczaj wspólnie to samo terytorium, przy czym czynniki etniczne, terytorialne i państwowe nie stanowią warunku koniecznego do ukształtowania wspólnoty narodowej. Profesor zauważył jednakże, że charakterystyczna cechą rodzących się wspólnot narodowych jest dążenie do samodzielności politycznej. (Zob. M. Handelsman, Rozwój narodowości nowoczesnych na Zachodzie europejskim, „Przegląd Współczesny” R. II, 1923, t. V, nr 14, s. 380, 387-388). Takie samo zdanie zaprezentowali Aleksander Lednicki i Leon Wasilewski, którzy uważali, że jedynym miarodajnym czynnikiem jest subiektywne poczucie świadomości narodowej, które może ulegać zmianom wraz z upływem czasu. (Zob. A. Lednicki, Idea narodowa i jej rozwój, „Przegląd Współczesny” R. VII, 1928, t. XXVI, nr 76, s. 179; L. Wasilewski, Narodowość wspótczesna, w: idem, Sprawy narodowościowe $w$ teorji $i w$ życiu, Warszawa-Kraków 1929, s. 1-14). Leon Wasilewski dodatkowo zwracał uwagę, że wspólnota narodowa często zostaje ukształtowana z pierwotnie odrębnych grup etnicznych, między którymi pod wpływem oddziaływania państwa, współżycia polityczno-społecznego, gospodarczego i kulturowego wytwarza się więź świadomości narodowej. Są to tzw. narody historyczne. (Ibidem, s. 10-11). Wydaje się, że ten sposób definiowania pojęcia narodu jest najwłaściwszy, choć nie do końca wspiera tezę o zbrodni dokonanej w rzeczywistości na polskiej grupie narodowej, gdyż zgodnie z ta definicją Ukraińcy i w mniejszym stopniu Białorusini w inkryminowanym czasie tworzyli odrębny naród, wyemancypowany z narodu Rzeczypospolitej. Osobne zagadnienie stanowi kwestia, na ile zamordowani na mocy decyzji katyńskiej mieli poczucie narodowości ukraińskiej czy białoruskiej, przeciwstawianej przynależności do narodu Rzeczypospolitej, a na ile byli oni zasymilowani z Polakami. Oczywiście przyjęcie tej definicji nie podważa argumentacji, że decydenci wydając dyrektywę o rozstrzelaniu polskich jeńców wojennych 
Warto więc się zastanowić, czy grupę zamordowanych nie można określić jako część grupy etnicznej II Rzeczypospolitej ${ }^{35}$.

W przypadku oskarżenia o zbrodnię ludobójstwa jedną z najtrudniejszych czynności jest udowodnienie dolus specialis zniszczenia w całości lub części grupy chronionej. Międzynarodowy Trybunał Karny dla Rwandy w sprawie Akayesu orzekł, że specyficzny zamiar nie musi być wyrażony wprost, a o jego zaistnieniu można wnioskować na podstawie faktów, takich jak ogólna doktryna polityczna generująca akty o dyskryminacyjnym i destrukcyjnym charakterze, a także same działania i ich rezultaty, plany ${ }^{36}$.

By udowodnić popełnienie zbrodni ludobójstwa, należy wykazać zamiar. Taka konstrukcja art. II Konwencji w sprawie zapobiegania i karania zbrodni ludobójstwa z 9 XII 1948 r. została zastosowana celowo, by nie ograniczać penalizacji zbrodni. Już wówczas przypuszczano, że sprawcy zbrodni ludobójstwa będą próbowali uniknąć odpowiedzialności, racjonalizując motywy, jakimi się kierowali, przesuwając niejako akcenty z najcięższej zbrodni ludobójstwa na inne mniej potworne, choć być może równie mocno potępiane przestępstwa. Manus I. Midlarsky w książce Ludobójstwo $w X X$ wieku wskazuje na to, że często masowe mordy dokonywane z motywów politycznych przeradzają się w ludobójstwo ${ }^{37}$.

i więźniów z terenów tzw. Zachodniej Białorusi i Zachodniej Ukrainy, docelowo zamierzali wymordować polską grupę narodowa. Nie można mieszać wykładni komentarza Kodeksu karnego z wykładnią obowiąującej ustawy karnej. Szacunek dla autorytetu prawa wymaga, by wybór między tymi dwiema odmiennymi wykładniami art. $152 \mathrm{kk}$ opierać na rzeczywistych, obiektywnych przesłankach. Nie może być to wybór podporządkowany potrzebom racji stanu, polityki historycznej czy wywodu argumentacyjnego narracji naukowej.

${ }_{35} \mathrm{Na}$ marginesie trzeba wspomnieć, że dotychczas w prawie definicja grupy etnicznej nie została sformułowana. Etnologia wskazuje najszersze traktowanie grupy etnicznej. Jednak większość prawników ujmuje mniejszość etniczną znacznie węziej, jako odrębną kulturowo grupę niemająca cech mniejszości narodowej. Tak też postrzegano grupy etniczne w dwudziestoleciu międzywojennym. (A. Fischer, Lud Polski. Podręcznik etnografji Polski, Lwów-Warszawa 1926, s. 9-12). W art. 513 wyroku Międzynarodowego Trybunału ds. Rwandy grupa etniczna została zdefiniowana jako grupa, której członkowie mają wspólny język lub kulturę. Dla nas istotna w definicji jest alternatywa określająca wspólny czynnik łączący członków grupy etnicznej, co pozwala nam stwierdzić, że choć obywatele II Rzeczypospolitej posługiwali się kilkoma językami, to jednak łączył ich pewien etos kulturowy. Orzecznictwo Międzynarodowego Trybunału ds. Rwandy. Jean Paul Akayesu, w: Prawo karne międzynarodowe..., s. 540.

${ }^{36}$ Orzecznictwo Międzynarodowego Trybunału ds. Rwandy, w: Prawo karne międzynarodowe..., s. 540.

${ }^{37}$ Choć autor książki nie rozumie, czym jest w prawie międzynarodowym zbrodnia ludobójstwa i posługuje się często uproszczeniami, zbliżonymi do potocznego rozumienia znaczenia słowa „ludobójstwo”, co w przypadku nie zawsze trafnie dobranych przykładów i licznych błędów w warstwie eksplikacyjnej narracji prowadzi do aberracji (zadziwiajace, że publikacja w Wydawnictwie Naukowym PWN dwukrotnie przeszła przez procedury recenzyjne), jest to spostrzeżenie trafne. M.I. Midlarsky, Ludobójstwo $w X X$ wieku, tłum. B. Wojciechowski, Warszawa 2010. 
Nie należy przy tym mylić zamiaru z motywem ${ }^{38}-\mathrm{w}$ prawie karnym sa to odrębne pojęcia. Dlatego udowodnienie zamiaru zniszczenia całości bądź części narodu polskiego pozwala na kwalifikację prawnokarną zbrodni katyńskiej jako zbrodni ludobójstwa, zaś wskazanie motywów, jakimi z punktu przyjętej racjonalności ogólnej mogły kierować się władze ZSRR, wydając tzw. decyzję katyńska, pozwala na zdefiniowanie jej jako zbrodni przeciwko ludzkości w ramach represji stalinowskich o charakterze politycznym. Mimo iż kwalifikacja prawna zbrodni katyńskiej budzi więcej kontrowersji niż jej kwalifikacja jako zbrodni dokonanej w ramach represji stalinowskich, to jednak łatwiej wykazać zamiar, jaki przyświecał sprawcom zbrodni, niż udowodnić motywy, jakimi się kierowali - w tym wypadku mamy wiele hipotez, które trudno jednoznacznie potwierdzić.

Witold Kulesza w artykule Zbrodnia katyńska jako akt ludobójstwa pisze: „Gdyby współcześnie pozostać przy określeniu Zbrodni Katyńskiej za pomoca jednego tylko pojęcia - jako zbrodni wojennej, oznaczałoby to pozostawienie poza refleksją prawną również celu jej popełnienia, jednoznacznie wskazanego w poleceniu z 5 marca 1940 roku, którego osiagnięciu miało służyć zarówno rozstrzelanie jeńców wojennych, jak i uwięzionych w więzieniach Białorusi i Ukrainy. Innymi słowy, pominięcie w kwalifikacji prawnokarnej tej zbrodni pojęcia ludobójstwa byłoby równoznaczne $\mathrm{z}$ uznaniem za prawnie nieistotne tego wszystkiego, co napisano o ofiarach, na uzasadnienie tego polecenia, wskazując dlaczego zostały zamordowane" ${ }^{39}$. Nie można na to pozwolić. Jesteśmy winni ofiarom pamięć i sprawiedliwość dziejowa. Po poznaniu faktografii zbrodni rodzi się naiwne pytanie o przyczyny - „dlaczego?” Pytanie to zamyka w sobie tragedię jeńców i więźniów, którzy zginęli, pozostawiając rodziny, bliskich, niezrealizowane plany, marzenia i szlachetne ideały, oraz dramat rodzin, które utraciły najbliższych. Dlatego historycy powinni wyjaśnić motywy zbrodni. Odpowiedź pozwoli na kwalifikację prawnokarną zbrodni. Nie możemy się godzić na kompromis dla dobra stosunków międzynarodowych w tej delikatnej kwestii, tak jak sugerował to członek "Memoriału” Aleksiej Pamiatnych ${ }^{40}$.

Zbrodnia katyńska wyraźnie miała charakter działania prewencyjnego przeciw państwu polskiemu. Zamordowani stanowili część elity narodu,

${ }^{38}$ Zob. B. Wróblewski, Motyw w prawie karnem, „Gazeta Sądowa Warszawska” R. XLIX, 1921, nr 10, s. 73-74.

${ }^{39}$ W. Kulesza, Zbrodnia katyńska jako akt ludobójstwa (geneza pojęcia), w: Zbrodnia katyńska. W kręu prawdy..., s. 55.

40 „Uważam, że możliwy jest kompromis nawet w kwalifikacji prawnej tej zbrodni. Wystarczy przyjąć, że nie było to ludobójstwo (moim zdaniem, żaden obiektywny prawnik nie udowodni tutaj ludobójstwa), ale zbrodnia wojenna, też nie podlegająca przedawnieniu. Tak, czy inaczej, osądzić nie ma już kogo - wszyscy zbrodniarze nie żyją" (A. Pamiatnych, Rosja a Katyń, w: Rosja a Katyń..., s. 16-17). To stanowisko jest nie do przyjęcia z punktu widzenia polskiej racji stanu i polskiej polityki historycznej. 
która mogła przyjać rolę przywódczą w walce o przywrócenie niepodległości Ojczyźnie. W notatce Berii 794/B znalazło się spostrzeżenie, że jeńcy „oczekują oswobodzenia, by uzyskać możliwość aktywnego włączenia się w walkę przeciwko władzy radzieckiej" ${ }^{41}$. Fizyczna eksterminacja elit miała zapobiec odrodzeniu się w oparciu o ich potencjał w przyszłości państwowości polskiej. Zaliczenie zamordowanych do potencjalnych grup politycznie niewygodnych dla okupanta sowieckiego nie wyklucza wszak, że stanowili oni przede wszystkim część elit niepodległościowych państwa polskiego. Ta wielokrotna klasyfikacja ofiar zbrodni jest oczywista i konieczna ${ }^{42}$. Sprawstwo kierownicze zbrodni katyńskiej abstrahowało od winy materialnej uwięzionych. Naczelnik Zarządu do Spraw Jeńców Wojennych Ludowego Komisariatu Spraw Wewnętrznych ZSRR mjr Soprunienko w grudniu 1939 r. występował do Berii z wnioskiem ${ }^{43}$, aby zatrzymanych $\mathrm{z}$ powodów klasowych nie kierować do obozów specjalnych. $Z$ tego wynika, że zamordowani nie stanowili grupy wrogiej klasowo wobec władzy komunistycznej. Kryterium doboru ofiar nie stanowiły również poglądy ideowe i polityczne jeńców, gdyż te, badane permanentnie przez politruków, były różnorodne, nawet jeśli chodzi o stosunek do państwa i ustroju sowieckiego. Powód wymordowania polskich jeńców stanowiła ich przynależność do narodu polskiego. Co najmniej 21819 polskich jeńców wojny obronnej 1939 r. i osadzonych w więzieniach wewnętrznych NKWD zostało wymordowanych na mocy jednej decyzji. Wyłączenie z grupy przeznaczonej do transportu na egzekucję było podejmowane indywidualnie w stosunku do poszczególnych ocalałych. Tutaj więcej mogłyby powiedzieć teczki personalne ofiar zakładane przez enkawudzistów, jednak historycy nie mają do nich dostępu.

Kazus Stanisława Swianiewicza ${ }^{44}$ świadczy o tym, że oskarżeni o przestępstwa polityczne byli odseparowywani od transportu. Strona radziecka $\mathrm{w}$ ostatniej chwili ${ }^{45}$ zmieniła profesorowi kwalifikację prawną z jeńca wojennego na więźnia politycznego oskarżonego z art. 58 § kk RFSRR o szpiegostwo

${ }^{41} 1940$ marzec 5, Moskwa - Notatka Ł. Berii do Stalina z propozycją wymordowania polskich jeńców wojennych, w: Katyń. Dokumenty zbrodni..., t. I, s. 470-471.

${ }^{42}$ Klasyfikacja zamordowanych na mocy decyzji KC WKP(b) z 5 III 1940 r. jako części grupy narodowościowej pozwala na kwalifikację zbrodni jako ludobójstwo, zaś klasyfikacja ich jako członków grupy politycznej wrogiej wobec systemu sowieckiego otwiera możliwość rehabilitacji ofiar dotkniętych represjami stalinowskimi.

43 1939, grudzień 29, Moskwa - Informacja P. Soprunienki dla Ł. Berii w sprawie postępowania z osobami aresztowanymi przez NKWD na terenie Zachodniej Białorusi i Ukrainy, w: Katyń. Dokumenty zbrodni..., t. I, s. 336-337.

${ }^{44}$ Por. S. Swianiewicz, W cieniu Katynia, Warszawa 1989.

${ }^{45}$ Kombryg Wasilij Zarubin zainteresował się nim dopiero, gdy Tadeusz Wirszyłło nieświadomie zdradził tożsamość profesora w marcu 1940 r. Swianiewicz w nocy 29/30 IV $1940 \mathrm{r}$. w ostatniej chwili został odseparowany od współjeńców transportowanych do stacji Gniezdowa, a jego relacja jest o tyle ważna, że był on tym jeńcem, który znajdował się najbliżej egzekucji w Kosogorach. 
na rzecz Rzeszy ${ }^{46}$. Kwalifikacja Swianiewicza jako więźnia politycznego dokonana przez Rosjan nie może ulec zaprzeczeniu, choć mogą się tu pojawić zastrzeżenia co do znaczenia terminu „więzień polityczny” w myśl sowieckiego wymiaru sprawiedliwości. Oczywiście Swianiewicz nie stanowił politycznego zagrożenia dla Sowietów. Chcieli oni jednak wykorzystać jego fachową wiedzę z zakresu gospodarki III Rzeszy i Rosji Sowieckiej być może do przygotowywanej przez Stalina wojny przeciw III Rzeszy ${ }^{47}$. Więzień polityczny ocalał, Sowieci wymordowali więc elitę narodu. Zbrodnia katyńska jest ludobójstwem popełnionym na grupie etnicznej II Rzeczypospolitej.

W perspektywie możliwości ukształtowania namiastki rządu polskiego podległego władzy radzieckiej, elity narodu, zamordowane na mocy decyzji z 5 III 1940 r., jawią się jako siła opozycyjna, narodowowyzwoleńcza. Dla przejrzystości argumentacji należy jednak zastanowić się, na ile stanowiła ona realne zagrożenie dla rządów komunistycznych. Oskarżeni byli wycieńczeni skrajnymi warunkami bytowymi, schorowani, nierzadko w podeszłym wieku, zdemobilizowani, niemajacy powiązań z organizacją konspiracyjna. Czy stanowili realne zagrożenie polityczne? $\mathrm{Z}$ pewnością byli niewygodni zarówno dla okupanta niemieckiego, jak i sowieckiego, ale zamknięci w obozach, więzieniach wewnętrznych NKWD mieli ograniczone możliwości działania. Historyk przyjmuje w procesie konstrukcji narracji racjonalność decydentów. Nie wie jednak, na ile jest to racjonalność właściwa w sensie ogólnym, a na ile jego własna racjonalność ex post. W przypadku systemów totalitarnych zadanie stojące przed historykiem może być trudniejsze ze względu na tzw. pierwiastek irracjonalny.

Sama decyzja KC WKP(b) z 5 III 1940 r., tak jak procesy śledcze prowadzone wobec jeńców obozu ostaszkowskiego z art. $58 \S 13^{48} \mathrm{kk}$ RFSRR, była bezprawna. Jeńcy wojenni i więźniowie pozostawali w niewoli, a podejmowane przez nich próby działania nie mogły przerodzić się w rzeczywiste czyny, toteż przejawiana przez nich wroga postawa wobec systemu sowieckiego,

${ }^{46}$ Teczka personalna prof. Swianiewicza była koloru białego, czym wyróżniała się spośród czerwonych teczek zamordowanych polskich jeńców.

${ }^{47}$ Za przesłankę możliwości współpracy politrucy mogli przyjąc światopogląd socjalistyczny, bowiem w młodości profesor był zwolennikiem PPS, a na swych wykładach poświęcał wiele czasu na omówienie koncepcji marksistowskiej, nieakceptowanej przez niego i uważanej za ahistoryczna. Sprawa ta przez długie lata była przemilczana w PRL, stąd zdarzają się osoby, które posądzają profesora o współpracę z Sowietami, łącząc jego sprawę z oficerami, których wcześniej potencjalnie próbowano zwerbować (grono oficerów z willi w Małachówce i Griazdowcu, którzy jednak nie zawsze szli na współpracę z bolszewikami). Trzeba jednak podkreślić, że nie podjął on żadnej współpracy z władzą radziecką w jakiejkolwiek formie. Po śledztwie na Łubiance i Butyrkach, skazany na 8 lat łagrów w Republice Komi, został uwolniony dzięki staraniom ambasadora Stanisława Kota. Znalazł się w ambasadzie w Kujbyszewie, a następnie został ewakuowany na Wschód wraz z Armią Polską pod dowództwem gen. Władysława Andersa i polską ambasadą.

${ }^{48}$ Paragraf penalizuje służbę w armii carskiej (również ex post). 
zneutralizowana przez czynniki obiektywne, nie miała znamion jakiegokolwiek przestępstwa. Decyzja z 5 III 1940 r. nie respektowała w stosunku do jeńców działania zarówno prawa międzynarodowego, jak i prawa wewnętrznego. Podporządkowanie ich jurysdykcji sowieckiej nie zgadzało się nie tylko z konwencją haską z 1907 r. ${ }^{49}$, której Rosja Sowiecka rzeczywiście nie była sygnatariuszka, ale także $\mathrm{z}$ międzynarodowym prawem zwyczajowym obowiązującym wszystkie cywilizowane państwa na zasadzie wzajemności.

Decyzja KC WKP(b) z 5 III 1940 r. została poprzedzona wydana trzy dni wcześniej decyzją o objęciu deportacją na 10 lat w rejony północnej Kazachskiej SRR rodzin represjonowanych i jeńców ${ }^{50}$. Władzom sowieckim nie wystarczyło zlikwidowanie nierokujacych nadziei na poprawę zatwardziałych wrogów ZSRR, pociagając do odpowiedzialności zbiorowo członków rodzin skazanych na śmierć, na podstawie art. 58 § 1 pkt c Kodeksu karnego z 1926 r. ${ }^{51}$ Komitet Centralny zatwierdził propozycję Ławrientija Berii i Nikity Chruszczowa objęcia deportacją na 10 lat w rejony północnej Kazachskiej SRR rodzin represjonowanych i jeńców ${ }^{52}$. Polecono aresztować i przygotować sprawy do rozpatrzenia przez Kolegium Specjalne NKWD „najbardziej zajadłych” członków rodzin jeńców, wobec których posiadano materiały obciążajace działalnością antysowiecką. W uchwale z 2 III 1940 i dyrektywie Berii z 7 marca skierowanej do ludowych komisarzy spraw wewnętrznych USRR i BSRR polecono jednostkom NKWD przeprowadzić do 15 kwietnia deportację rodzin represjonowanych i przebywajacych w obozach jenieckich byłych oficerów armii polskiej, byłych polskich funkcjonariuszy i urzędników państwowych, byłych właścicieli ziemskich i przedsiębiorców w liczbie szacowanej na 22-25 tys. rodzin. Nagromadzenie słowa „były” wskazuje na neutralizację jeńców, a przymiotnik „polski” potwierdza, że docelowa grupa obu decyzji była grupa narodowościowa. Wraz z rodzinami jeńców wojennych i przebywających w więzieniach wewnętrznych objętych decyzją katyńską deportowani zostali uciekinierzy z terytorium okupowanego przez Niemców i prostytutki.

Decyzja z 2 III 1940 r. świadczy o tym, że koncepcja rozstrzygnięcia kwestii polskich jeńców wojennych i osadzonych w więzieniach wewnętrznych NKWD

${ }^{49}$ Konwencja haska z 1907 r. stanowiła, że jeńcy wojenni nie podlegali odpowiedzialności sądowo-karnej poza przypadkiem złamania słowa honoru.

501940 marzec 2, Moskwa - Wyciąg z protokołu nr 13 posiedzeń Biura Politycznego KC WKP(b). Decyzja o ochronie granicy państwowej w zachodnich obwodach USRR i BSRR, w: Katyń. Dokumenty zbrodni..., t. I, s. 460-462.

${ }^{51}$ Paragraf ten był narzędziem wyniszczenia rodziny skazanego za przestępstwo kontrrewolucyjne, nawet jeśli nie współdziałała z nim w inkryminowanym czynie, a nawet nie wiedziała ona o jego działalności skierowanej przeciw ustrojowi Związku Sowieckiego.

${ }^{52} 1940$ marzec 2, Moskwa - Wyciag z protokołu nr 13 posiedzeń Biura Politycznego KC WKP(b). Decyzja o ochronie granicy państwowej w zachodnich obwodach USRR i BSRR, w: Katyń. Dokumenty zbrodni..., t. I, s. 460-461. 
musiała zostać sformułowana jakiś czas przed prawnym usankcjonowaniem akcji rozładowania więzień i obozów jenieckich. Biorąc pod uwagę zagrażające życiu warunki transportu panujące na stepach kazachskich, można wykazać, że zgodnie z międzynarodową definicją ludobójstwa obie decyzje, tj. z 2 i 5 III 1940 r., miały na celu eksterminację części grupy narodowościowej.

Kontekst zbrodni katyńskiej stanowiło wymierzone we wszystkie warstwy społeczne niszczenie polskości na obszarze okupacji sowieckiej, obejmujące m.in. deportację setek tysięcy Polaków w głąb ZSRR w celu etnicznego wyczyszczenia Kresów II Rzeczypospolitej. Tylko 13 kwietnia i w ciagu kilku kolejnych dni 1940 r. wywieziono ze wschodnich terenów Polski do Kazachstanu przeszło 61 tys. członków rodzin jeńców mordowanych w tym samym czasie w Katyniu, Charkowie i Twerze, z czego 80\% stanowiły kobiety i dzieci. Polityka władz radzieckich po 17 IX 1939 r. była kontynuacją eksterminacji narodu polskiego na terenach zagarniętych. Analogicznych zbrodni ludobójstwa dokonano w okresie tzw. Wielkiego Terroru w ramach operacji polskiej w latach 1937-1938 wobec obywateli Rzeczypospolitej pozostałych po traktacie ryskim za linią Curzona. Tutaj warto wspomnieć o zbrodni w Winnicy - nazywanej nieprzypadkowo preludium Katynia, odkrytej przez Niemców 25 V 1943 r.

Uchwałę z 5 III 1940 r. można oceniać również jako sprawstwo konsekutywne (następcze) eksterminacji narodu polskiego rozpoczętej przez władze III Rzeszy już we wrześniu 1939 r. na terenach okupowanych, bez zastrzeżeń kwalifikowanej w kategoriach ludobójstwa wymierzonego w elity narodu. Nie wiemy, na ile eksterminacja elit przez Sowietów była skoordynowana $\mathrm{z}$ akcja $\mathrm{AB}$ (Ausserordentliche Befriedungsaktion). Zwraca uwage zbieżność czasu przeprowadzania masowych egzekucji na podstawie tzw. decyzji katyńskiej i egzekucji w Palmirach. Enigmatyczne pozostają dwie konferencje NKWD i Gestapo w Zakopanem i pokonferencyjne spotkanie w Krakowie ${ }^{53}$. Wydaje się, że Niemcy nie wiedzieli nic konkretnego o zbrodniach sowieckich, poza tym, że były przeprowadzane, ale sami nie ukrywając swych zbrodni, niejako zachęcali do wypełnienia sojuszniczego zobowiązania z 23 VIII $1939 \mathrm{r}$.

Komisja ekspertów powołana przez Główną Prokuraturę Wojskową Federacji Rosyjskiej w orzeczeniu z 2 VIII $1993 \mathrm{rr}^{54}$ stwierdziła, że istnieją wszelkie podstawy do tego, by oceny prawnej zbrodni katyńskiej dokonać zgodnie z przepisami statutu Międzynarodowego Trybunału Wojennego, odnosząc do niej zarówno art. 6 pkt b traktujący o zbrodniach wojennych, jak i art. 6 pkt c mówiący o zbrodniach przeciwko ludzkości. Unieważnienie opinii komisji ekspertów świadczy o tym, że strona rosyjska odmawia uznania zbrodni za eksterminację narodowościową równoznaczną z ludobójstwem.

\footnotetext{
${ }^{53}$ Por. A. Kaczyński, Wspólnicy zbrodni, „Rzeczpospolita”, 4 III 2010, dodatek „Zagłada elit”, s. 7.

${ }^{54}$ Orzeczenie komisji ekspertów (2 sierpnia 1993)..., w: Rosja a Katyń..., s. 69.
} 
Dla Rodzin Katyńskich i pamięci historycznej Polaków kwestią zasadniczą jest potwierdzenie przez kompetentne organy Federacji Rosyjskiej kwalifikacji prawnej zbrodni katyńskiej jako niepodlegajacej przedawnieniu zbrodni wojennej oraz zbrodni przeciwko ludzkości w jej najcięższej postaci, jaką stanowi ludobójstwo. Nie jest znana treść dokumentu zamykającego przez umorzenie śledztwo nr $159 \mathrm{w}$ katyńskiej sprawie karnej prowadzone przez Główna Prokuraturę Wojskową Federacji Rosyjskiej w latach 1990-2004, który określa kwalifikacje prawnokarną zbrodni w myśl rosyjskiego wymiaru sprawiedliwości, toteż historycy nie mają możliwości odnieść się w polemicznym dyskursie do argumentacji strony rosyjskiej.

Nie można oczekiwać osądzenia zbrodni katyńskiej na podstawie prawnej wyrażonej w Statucie Międzynarodowego Trybunału Wojennego, gdyż przepisy te odnoszą się wyłącznie do zbrodni popełnionych przez państwa Osi w czasie II wojny światowej. Prawo międzynarodowe posiada jednakże mechanizmy pozwalające na kwalifikację prawnokarną zbrodni przez kompetentny organ sądowniczy na podstawie Statutu Rzymskiego Międzynarodowego Trybunału Karnego ${ }^{55}$, na co w myśl art. $11 \S 2$ zgodę wyrazić musiałaby strona pozwana. Tutaj warto podkreślić, że Statut Rzymski sankcjonuje możliwość osądzenia prawnokarnego zbrodni w myśl artykułów zredagowanych ex post, gdyż pojęcia prawne, do których się odnosi, istniały wcześniej w prawodawstwie międzynarodowym i krajowym. Natomiast art. 1 Konwencji o niestosowaniu przedawnienia wobec zbrodni wojennych i zbrodni przeciwko ludzkości ${ }^{56}$ stanowi, że zbrodnie te nie ulegaja przedawnieniu, bez względu na datę ich popełnienia i nawet $\mathrm{w}$ przypadku, jeżeli czyny takie nie naruszaja prawa wewnętrznego kraju, w którym zostały dokonane. Zapisy konwencji sankcjonuja prawnie możliwość osądu zbrodni popełnionej przed 1968 r., a więc także w czasie II wojny światowej, zgodnie z przepisami prawa międzynarodowego, nawet jeśli nie zostały one ratyfikowane przez stronę pozwana.

\section{Streszczenie}

W artykule omówiono kwalifikację zbrodni katyńskiej w kategoriach zbrodni ludobójstwa. Odwołujacc się do bipenalizacji zabójstw, podważono zarzut lex retro non agit w stosunku do określania zbrodni w kategoriach ludobójstwa zdefiniowanego ex post po wojnie. Analizując definicję prawną zbrodni ludobójstwa, wskazano grupę chroniona - etniczną grupę obywateli II Rzeczypospolitej tożsamą w rozumieniu sprawców zbrodni z grupą narodowościową polską - przeciwko której skierowano zbrodniczą decyzję z 5 III 1940 r., wpisując ją w szerszy kontekst działań ZSRR przeciwko obywatelom polskim w zasięgu sowieckiej jurysdykcji. Abstrahując od motywów zbrodni, wykazano dolus specialis - zamiar zniszczenia polskich jeńców wojennych i więźniów więzień na terenie tzw. Zachodniej Białorusi i Zachodniej Ukrainy.

${ }^{55}$ Rzymski Statut Międzynarodowego Trybunału Karnego, w: G. Jędrejek, Z. Peszkowski, op. cit., s. 500-501.

${ }^{56}$ Konwencja o niestosowaniu przedawnienia wobec zbrodni wojennych i zbrodni przeciwko ludzkości, w: G. Jędrejek, Z. Peszkowski, op. cit., s. 487. 


\section{Katyn Massacre as genocide. An attempt at systematisation of its criminal legal qualification}

The article discusses the legal qualification of the Katyn Massacre in the categories of genocide. Referring to the double penalisation of killing, the claim of retroactivity of the law was dismissed in regard to Katyn Massacre regarded as the category of crime defined after the war. After an analysis of the legal definition of genocide, a protected group was indicated - the ethnic group of citizens of the Second Polish Republic, who in the understanding of the perpetrators of the crime were identified with a national Polish group - against whom the decision about killing was issued on 5 March 1940, inscribing it into a broader context of actions undertaken by the USSR against Polish citizens within the Soviet jurisdiction. Aside from the motivations of the crime, its special deceit (dolus specialis) was indicated, that is the specific intent to kill Polish prisoners of war and inmates of prisons located in the territory of the so-called West Belarus and Ukraine.

\section{Bibliografia}

Ancewicz F., Stalinowska koncepcja państwa na tle ewolucji ustrojowej Zwiazku Socjalistycznych Republik Radzieckich, Lublin 2001.

Ehrlich S., Państwo Radzieckie, seria: „Biblioteka Wiedzy o Związku Radzieckim”, nr 1, Warszawa 1950.

Fischer A., Lud Polski. Podręcznik etnografji Polski, Lwów-Warszawa 1926.

Grzybowski K., Ustrój Zwiazku Socjalistycznych Sowieckich Republik, „Przegląd Współczesny” R. VII, 1928, t. XXVII.

Handelsman M., Rozwój narodowości nowoczesnych na Zachodzie europejskim, „Przegląd Współczesny” R. II, 1923, t. V, nr 14.

Iwanow M., Pierwszy naród ukarany. Stalinizm wobec polskiej ludności kresowej (1921-1938), Warszawa 1991.

Jankiewicz A., Przygotowania Rzadu RP w latach II wojny światowej do procesu zbrodniarzy hitlerowskich. Dekret prezydenta Rzeczypospolitej o odpowiedzialności karnej za zbrodnie wojenne, „Pamięć i Sprawiedliwość” 1997-1998, nr 40.

Jędrejek G., Peszkowski Z., Zbrodnia katyńska w świetle prawa, Warszawa-Pelplin 2004.

Kalbarczyk S., Zbrodnia katyńska po 70 latach. Krótki przeglad ustaleń historiografii, w: Zbrodnia katyńska. W kregu prawdy i kłamstwa, red. S. Kalbarczyk, Warszawa 2010.

Kostrzewski A., Prawne aspekty zbrodni katyńskiej, seria: „Zeszyty Katyńskie”, nr 8: Ku cmentarzom polskim w Katyniu, Miednoje, Charkowie, Warszawa 1997, s. 52-61.

Kowalski K., Polski kodeks karny w dotychczasowej praktyce, „Czasopismo Sędziowskie” R. VIII, 1934, nr 3.

Kurczab J., Struktura narodowościowa i wyznaniowa Ofiar Zbrodni Katyńskiej, opracowanie wewnętrzne Centralnej Biblioteki Wojskowej im. Marszałka Józefa Piłsudskiego w Warszawie, Warszawa 2015.

Lednicki A., Idea narodowa i jej rozwój, „Przegląd Współczesny” R. VII, 1928, t. XXVI, nr 76.

Lemkin R., Axis Rule in Occupied Europe. Laws of Occupation, Analysis of Government, Proposals for Redress, Washington 1944.

Makarewicz J., Wyktadnia kodeksu karnego. Naród Polski, „Gazeta Sądowa Warszawska” R. LXI, 1934, nr 26, s. 386-388.

Materski W., Gruzini - ofiary zbrodni katyńskiej. Dokument z postsowieckiego zasobu archiwalnego, „Pro Georgia” 2004, nr 11, s. 89-93.

Midlarsky M.I., Ludobójstwo w XX wieku, tłum. B. Wojciechowski, Warszawa 2010.

Rosja a Katyń, red. A. Dzienkiewicz, Warszawa 2010. 
Swianiewicz S., W cieniu Katynia, Warszawa 1989.

Trial of the Major War Criminals before International Military Tribunal. Official Text, t. VII, Nuremberg 1974.

Wasilewski L., Sprawy narodowościowe w teorji i w życiu, Warszawa-Kraków 1929.

Wielhorski W., Los Polaków w niewoli sowieckiej (1939-1956), Londyn 1956.

Wróblewski B., Motyw w prawie karnem, „Gazeta Sądowa Warszawska” R. XLIX, 1921, nr 10. Zamorski K., Starzewski S., Sprawiedliwość sowiecka, Warszawa 1994.

Bi g r a m: Joanna Kurczab - dr; obecnie zawodowo związana z Instytutem Nauk Prawnych PAN. Autorka kilkunastu publikacji naukowych i popularnonaukowych dotyczących zbrodni katyńskiej (m.in. współautorska książki „....wierzymy mocno, że wrócisz...” Korespondencja wydobyta z dołów śmierci Charkowa i Miednoje ze zbiorów Muzeum Katyńskiego, Warszawa 2016) i zbrojnego podziemia niepodległościowego po 1945 r. E-m a il: joannakurczab@poczta.onet.pl. 